\title{
Legal Protection on Indigenous Herbs of Madura through Geographical Indications
}

\author{
Habib Adjie, Tanudjaja, Woro Winandi, and Moh. Saleh ${ }^{1 *}$ \\ ${ }^{1}$ Lecturers at the Law Faculty of of Narotama University, Surabaya, Indonesia.
}

\begin{abstract}
Indigenous Herbs of Madura is the productt of intellectual creativity of local community in Madura which spread over four regions, namely Bangkalan, Sampang, Pamekasan, and Sumenep. Indigenous Herbs of Madura is part of traditional medicine which produced heredity by Madurese society. To prevent misappropriation from developed countries, the Indigenous Herbs of Madura must be legally protected. The model of legal protection of the Indigenous Herbs of Madura can be done using Geographical Indication Certificate of the Government of East Java Province or by an institution or association of the entrepreneurs of Indegenous Herbs of Madura with its membership covering four regions in Madura. The Geographical Indication Certificate becomes the basis for granting permission to utilize the original ingredients of Madurese by either local entrepreneur or other local business in Madura, or by foreign entrepreneur. In the event that such utilization permits are granted against a local business entrepreneur in Madura or to a foreign entrepreneur, a prior informed consent of Madurese (prior informed consent) and benefit sharing is required for the local community in Madura.
\end{abstract}

\section{Introduction and Literature Review}

Indigenous Herbs of Madura is part of traditional medicine which is hereditary by Madurese society. To prevent the misappropriation from developed countries, the Indigenous Herbs of Madura must be legally protected [1]. The Indigenous Herbs of Madura is an intellectual creative product from local people of Madura that is hereditary and become collective rights. It can be found in four regions of Madura, namely Bangkalan, Sampang, Pamekasan and Sumenep. Madura is an Indonesian island of the northeastern coast of Java as well as a part of East Java province. Several types of Indigenous Herbs of Madura found in four districts in Madura can be identified as in the following table [2]:

Table 1. Types of Indigenous Herbs of Madura

\begin{tabular}{|c|l|c|l|}
\hline No & $\begin{array}{c}\text { Types of Indigenous Herbs of } \\
\text { Madura }\end{array}$ & No & \multicolumn{1}{|c|}{$\begin{array}{c}\text { Types of Indigenous Herbs of } \\
\text { Madura }\end{array}$} \\
\hline 1 & Ma'jun Raja & 12 & Penyubur Kandungan \\
\hline 2 & Sehat Pria/Perkasa & 13 & Galian Wanita \\
\hline 3 & Jantala/Tahan Lama & 14 & Galian Patmosari \\
\hline
\end{tabular}

\footnotetext{
* Corresponding author: saleh.nwa@gmail.com
} 


\begin{tabular}{|c|l|c|l|}
\hline 4 & Galian Rapet & 15 & Spesial Keputihan \\
\hline 5 & Dalima (Keputihan) & 16 & Kunir Putih \& Temu Putih \\
\hline 6 & Galian Sehat (Montok) & 17 & Asam Urat \& Kolesterol \\
\hline 7 & Pegal Linu & 18 & Legit Madura (Cempaka Putih) \\
\hline 8 & Selokarang & 19 & Kecantikan \\
\hline 9 & Harumita (Empot Super) & 20 & Sumirat \\
\hline 10 & Galian Singset (Susut Perut) & 21 & Jamu Maag \\
\hline 11 & Remaja Puteri & 22 & Bangkes \\
\hline
\end{tabular}

The listed Indigenous Herbs of Madura manufactures are 124 (one hundred and twentyfour) companies, which consist of individual, corporate companies and non-legal entities. The forms of the Indigenous Herbs of Madura companies are as follows [3]:

Table 2. Forms of the indigenous herbs of Madurese companies

\begin{tabular}{|c|c|c|c|c|c|c|}
\hline \multirow[b]{2}{*}{$\begin{array}{l}\mathrm{N} \\
\mathrm{o}\end{array}$} & \multirow{2}{*}{$\begin{array}{l}\text { Names of } \\
\text { District }\end{array}$} & \multicolumn{5}{|c|}{ Companies Forms } \\
\hline & & Individual & $\begin{array}{c}\text { Sole } \\
\text { Proprietorship }\end{array}$ & $\begin{array}{l}\text { Coommanditair } \\
\text { e Vennootschap }\end{array}$ & $\begin{array}{l}\text { Limited } \\
\text { Company }\end{array}$ & $\begin{array}{c}\text { Tot } \\
\text { al }\end{array}$ \\
\hline 1 & Bangkalan & 6 & 15 & 1 & - & 22 \\
\hline 2 & Sampang & 4 & 1 & - & - & 5 \\
\hline 3 & Pamekasan & 24 & - & - & 1 & 25 \\
\hline 4 & Sumenep & 60 & 11 & 1 & - & 72 \\
\hline & Total & 94 & 27 & 2 & 1 & 124 \\
\hline
\end{tabular}

Indigenous Herbs of Madura which is hereditary produced cannot be claimed individually, but it is owned collectively by all members of local society in Madura. WIPO Report on Fact Finding Mission on Intellectual Property and Traditional Knowledge (19981999) has provided an explanation of the concept of traditional knowledge ownership. According to WIPO that the so-called owner of traditional knowledge is everyone who creates, develops, and practices traditional knowledge in traditional rules and concepts.

Indigenous people, local society, and the state are the owners of traditional knowledge. Thus, in this traditional knowledge protection, the common interest (communal) is put forward rather than individual interests [4]. Protecting communal interests are ways to maintain a harmonious life between one another so that a maker of a traditional medicine produced by a member of society will not cause any constraints if the other members also make a similar work [5]. On this basis, the Indigenous Herbs of Madurese as part of the traditional knowledge applies the concept of collective ownership. In other words, this 'collectively' is not in the group of individuals, but it is in the sense of ownership by the local or local people concerned, whether organized or not [6].

The process of making and developing the Indigenous Herbs of Madura is done traditionally, that is transmitted from generation to generation so that the original ingredients of Madura are merged in the culture and personality of Madurese society. On this basis, the Indigenous Herb of Madura is referred to as a cultural heritage and cultural identity in Madurese society. Cultural heritage and cultural identity are not obtained in an easy way, but obtained from the hundreds year's process of the community associations and the utilization of traditional medicine materials. Therefore, acquisition process of the Indigenous Herbs of Madura is more difficult than the acquisition of current modern medicine. It involves cultural and social interaction with the natural surroundings which takes a very long time. While current modern medicine only involves technological advances and only takes a very short 
time. Based on this, then the original herb Madura has a value that is much more expensive and valuable than the current made modern medicine[7].

\section{Objective of the Study}

This study aims to analyze the model of legal protection against the Indigenous Herbs of Madura through the Geographical Indication according to Law Number 20 of 2016 concerning Trandemark and Geographical Indications.

\section{Methodology}

This study is conducted with literature and statute review. The purpose of this review is to get answer regarding legal issue. The interviews help the authors to understand the Indigenous Herbs of Madura and to explore the relevant issue in depth. The author interviewed the entrepreneurs of Indigenous Herbs of Madura and public officers of Health Office, Trade Service, and the officers of Cooperative, Micro, Small and Medium Enterprises in Bangkalan, Sampang, Pamekasan, and Sumenep.

\section{Discussion}

Geographical Indication Concept according to Paris Convention regarding the Protection of Industrial Property on 1983 is "Indication of Source as an indication referring to a country or a place in that country, as being the country or place of origin of a product". More details in accordance with Article 22 of the TRIPs Agreement that "Geographical indications are for the purposes of this agreement, the indications which identify a good as originating in the territory of a member, or a region or locality in that territory, where a given quality, reputation or other characteristics of the good, is essentially attributable to its geographical origin". [8]

The concept of geographical indication mentioned above has in common with Article 1 Sub-Article 6 Law Number 20 of 2016 concerning Trandemark and Geographical Indications (Law Number 20 of 2016), that "Geographical Indication is a sign that indicates the origin of an item and / or products due to geographic environmental factors including natural factors, human factors or a combination of both factors provide a reputation, quality, and certain characteristics of the goods and / or the resulting product."

Unification of regulation concerning Geographical Indication and Trademark in Law Number 20 of 2016 is needed since there will be synergy between Geographical Indication with brand as a trademark. However, specificity for Geographical Indications, trademark that indicates original item and / or product due to natural factors, human factors or a combination of these two factors, will give a reputation, quality, and certain characteristics of the goods and / or the resulting product.

Based on the above description, the Indigenous Herbs of Madura is included in the concept of Geographical Indication, because the original ingredients of Madura are produced by descending with collective ownership. The reputation, quality, and characteristics are contained in each type of the Indigenous Herbs of Madura. Therefore, the legal protection of the original Madurese Potion is done through the registration of each type of Original Madurese Potions.

Registration of Geographical Indication of the Indigenous Herbs of Madura submitted to the Minister of Justice and Human Rights in accordance with the provisions stipulated in Law Number 20 of 2016 and other implementing regulations. According to Article 53 paragraph (3) Law Number 20 of 2016 it is stipulated that the applicant of Geographical Indication shall be: 
a. Institutions representing communities in a certain geographic region that seeks goods and / or products in the form of natural resources, handicrafts, or industrial products; and

b. National or local government

Based on the provisions of Article 53 paragraph (3) Law Number 20 of 2016 above, the applicant of Geographical Indication of the Indigenous Herbs of Madura is the foundations or the association of Indigenous Herbs of Madura's entrepreneurs based in Madura or the East Java Provincial Government. As for the local District Government in Madura is unable to perform the registration of Geographical Indications on Indigenous Herbs of Madura, because the existence of Indigenous Herbs of Madura manufactured and traded by the local community in Madura across four districts in Madura. Every administration of municipal government affairs across districts or municipalities becomes the authority of the province, as defined in Article 13 paragraph (3) Law Number 23, 2014 concerning Local Government, namely:

Based on the principle as referred to in paragraph (1) the criteria of Government Affairs which is the authority of the Provincial Region is:

a. Government Affairs whose location is across Districts / Municipalities;

b. Government Affairs whose users cross Districts / Municipalites;

c. Government Affairs whose benefits or negative impacts are across districts/ Municipalities, and/or;

d. Government Affairs that use their resources more efficiently if done by the Provincial Region.

Under condition that the Government of East Java Province does not register Geographical Indication of Indigenous Herbs of Madura, an institution or association or organization of Indigenous Herbs of Madura entrepreneurs based in Madura can perform the registration according to Article 53 paragraph (3) Law Number 20 of 2016 above. Based on the results of the research is known that the institution or association or organization of Indigenous Herbs of Madura entrepreneurs is only available in Pamekasan Regency under the name of Industri Jamu Tradisional Madura "POTRE MADURA" with 15 members of IKM (Industri Kecil Menengah/Small and Medium Industries) and H. Imam Suhairi as chairman. To be able to register Geographical Indication of Indigenous Herbs of Madura establishment of an institution or association or organization of Indigenous Herbs of Madura entrepreneurs from all Madura's districts, whose members cross the four districts in Madura are needed.

Legal protection through Geographical Indications shall be in accordance with the principle of first to file. Therefore, to obtain legal protection on the Indigenous Herbs of Madura, the Government of East Java Province or institution / associatioan / organization of Indigenous Herbs of Madura entrepreneurs in Madura must be submitted an application to the Minister of Law and Human Rights to get the Certificate of Geographical Indication.

East Java Provincial Government or institution / association / organization of Indigenous Herbs of Madura entrepreneurs in Madura who applied for registration and has obtained the Geographical Indication Certificate to the Right Holder of Geographical Indication of Indigenous Herbs of Madura. The Geographical Indicative Rights holders of the Indigenous Herbs of Madura has the exclusive rights granted by the nation as long as the reputation, quality, and characteristics underlying the protection of the Geographical Indication still exist in the Madurese original herb.

The Geographical Indicative Rights holder of the Indigenous Herbs of Madura has the authority to give permission to each user of the geographical indication that will perform the processing and / or marketing of Indigenous Herbs of Madura. The utilization permit of the Indigenous Herbs of Madura by the right holders of the Indigenous Herbs of Madura to the users of the Geographical Indication of the Indigenous Herbs of Madura shall not violate the provisions of law and harming the economic interest for the local community in Madura. So that the utilization of Indigenous Herbs of Madura does not violate the provisions of the 
legislation, the holder of rights to the Indigenous Herbs of Madura must create and enforce licensing requirements for the users of Geographical Indications on Indigenous Herbs of Madura. So that utilization of Madura Original herb does not harm the economic interests of the local community in Madura, the permit utilization on Indigenous Herbs of Madura should be given to local entrepreneurs in Madura. In terms of utilization license on Indigenous Herbs of Madura given to other than the local entrepreneurs in Madura or even to foreign company, should be coupled with the requirements for approval of the local community in Madura (prior informed consent) and must be accompanied with benefit sharing (profit sharing) between the user of the Geographical Indication of Indigenous Herbs of Madura with local people in Madura.

The right holder of Geographic Indication of Indigenous Herbs of Madura may revoke the utilization permit which has been granted to the user of geographical indication of Indigenous Herbs of Madura in case if it has not been able to maintain and guarantee the reputation, quality, and characteristic on which the protection of Geographical Indication of Indigenous Herbs of Madura. Therefore, the ability to guarantee and maintain the reputation, quality, and characteristics of the Indigenous Herbs of Madura should be included in the requirements for permit granting for the utilization of the Indigenous Herbs of Madura. The ability to guarantee and maintain the reputation, quality, and characteristics of the Indigenous Herbs of Madura can be seen in the field of equipment, human resources and finance to process the Indigenous Herbs of Madura. The concept of the license for users of Geographical Indications on Indigenous Herbs of Madura is according to Article 1 paragraph (10) Law Number 20 of 2016 that "The User of Geographical Indication is a party that has license from the holder of Rights to Geographical Indications registered to process and / or market goods and / or products Geographical Indication".

Based on the description above, the legal protection of the Indigenous Herbs of Madura through Geographical can be depicted in the following chart:

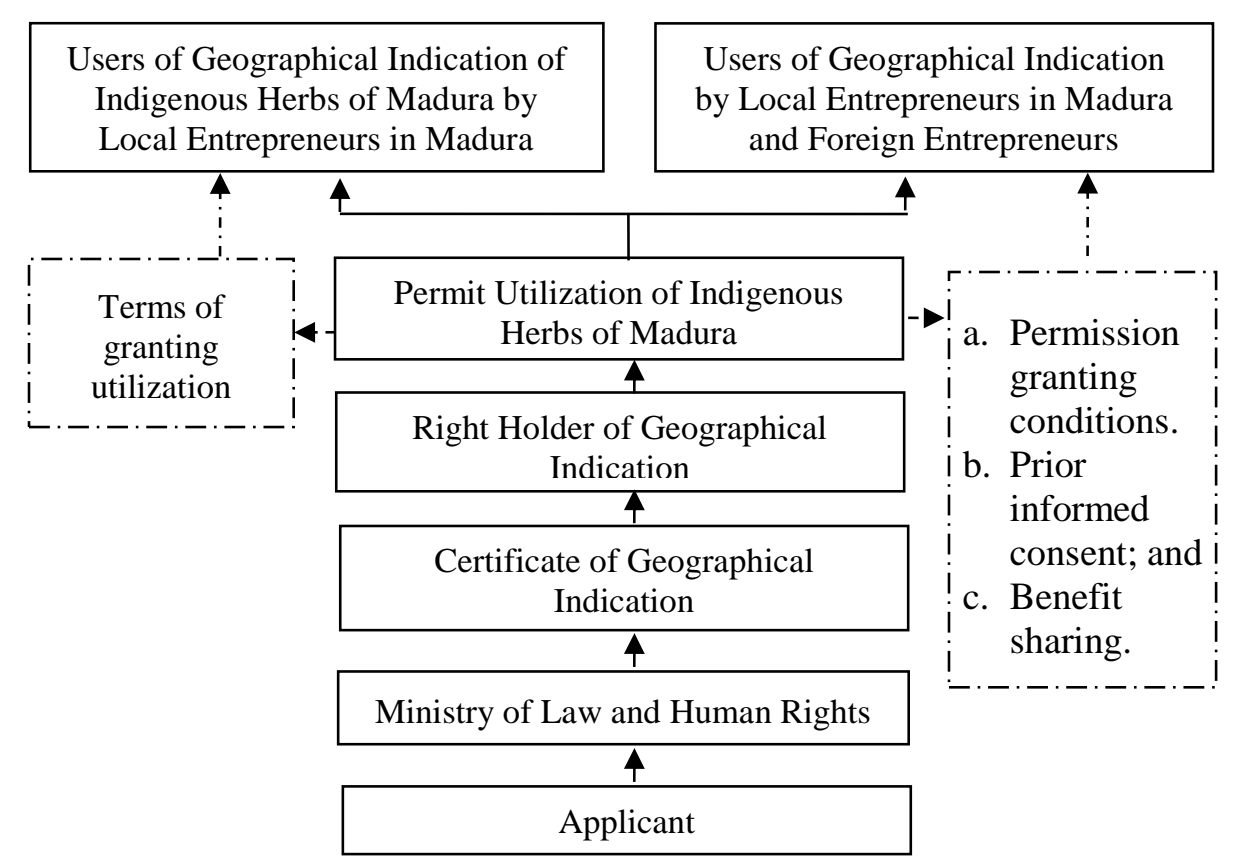

Figure 1. Model of Legal Protection for Indigenous Herbs of Madurese through Geographical Indication 


\section{Conclusion}

Based on the above discussion, the model of legal protection for the Indigenous Herbs of Madura through Geographical Indication can be done through the registration of geographical indication application towards the Ministry of Law and Human Rights of the East Java Provincial Government or by the institution or association or the organization of the Indigenous Herbs of Madura entrepreneurs whose membership covers the four districts in Madura. The registration of geographical indication is submitted about the types of the Indigenous Herbs of Madura. In the event that the Geographical Indication Certificate has been obtained, the holder of the geographical indication rights shall be authorized to grant a utilization permit to a local entrepreneur in Madura or to a non-local entrepreneur in Madura or to a foreign entrepreneur. The grant of such utilization permit ought to be coupled by the requirement of not violating the provisions of laws and regulations, not harming the interests of the local community in Madura, and can ensure the reputation, quality and characteristics of the Indigenous Herbs of Madura. In terms of the utilization permit of the Indigenous Herbs of Madura given to other than local entrepreneur in Madura or to foreign company, it must be coupled with the consent of the local society in Madura (prior informed consent) and also must be enclosed with the benefit sharing agreement for the local society in Madura.

\section{References}

1. S. Mawardi, "Establishment of Geographical Indication Protection System in Indonesia, Case in Coffee," Worldwide Symposium on Geographical Indications jointly orginized by the World Intellectual Property Organization (WIPO) and the Patent Office of the Republic of Bulagaria, Sofia, June 10 - 12, 2009.

2. The Interview conducted with Some Companies of Indigenous Herbs of Madura (July, 2017)

3. The Interview conducted at Health Office, Trade Service, and Office of Cooperative, Micro, Small and Medium Enterprises in Four Districts in Madura (July, 2017).

4. A. Purba, et. al., TRIPs - WTO \& Hukum HKI Indonesia, Kajian Perlindungan Hak Cipta Seni Batik Tradisional Indoensia (Rineka Cipta, Jakarta, 2005).

5. I.B. Maulana, 1997, Sukses Bisnis Melalui Merek, Paten dan Hak Cipta (Citra Aditya Bakti, Bandung, 1997).

6. A. Sardjono, Hak Kekayaan Intelektual dan Pengetahuan Tradisional (Alumni, Bandung, 2006).

7. The Interview conducted with the Indigenous Herbs of Madura entrepreneurs in Bangkalan, Sampang, Pamekasan, and Sumenep (Juli, 2017)

8. WIPO, Intellectual Property Needs and Expectations of Traditional Knowledge Holders: WIPO Report on Fact-Finding Missions on Intellectual Property and Traditional Knowledge 1998-1999 (WIPO, Geneva, 2001). 